\title{
Assemblage of immature Odonata (Insecta, Anisoptera) in streams of the Mato Grosso do Sul State: spatial implications
}

\author{
Juliane A. C. Soares ${ }^{1,2}$, Valéria F. Batista-Silva ${ }^{1,2}$, Daiane D. Boneto',2, Dayani Bailly ${ }^{2,3}$, \\ Milza C. F. Abelha',2 \& lana A. D. V. de Oliveira ${ }^{4}$ \\ 1. Universidade Estadual de Mato Grosso do Sul, BR 163, km 20,2, 79980-000 Mundo Novo, MS, Brazil. (vfb_silva@uems.br) \\ 2. Grupo de Estudos em Ciências Ambientais e Educação (GEAMBE), BR 163, km 20,2, 79980-000 Mundo Novo, MS, Brazil. \\ 3. Universidade Estadual de Maringá, PNPD/CAPES, PEA/NUPELIA, Av. Colombo, 5790, 87020-900 Maringá, PR, Brazil. \\ 4. PPG em Meio Ambiente e Desenvolvimento Regional, Universidade Estadual de Mato Grosso do Sul, BR 163, km 20,2, $79980-000$ Mundo Novo, MS, Brazil.
}

\begin{abstract}
This study investigated the assemblages attributes (composition, abundance, richness, diversity and evenness) and the most representative genera of Odonata, Anisoptera at Água Boa and Perobão Streams, Iguatemi River basin, Brazil. Both are first order streams with similar length that are impacted by riparian forest removal and silting. Quarterly samplings were conducted from March to December 2008 in the upper, intermediate and lower stretch of each stream. The Mantel test was used to check the influence of spatial autocorrelation on the Odonata composition. Spatial variations in the composition were summarized by the Principal Coordinates Analysis (PCoA) using Mantel test residuals. The effects of spatial correlation on richness and abundance were investigated by the spatial correlogram of Moran's I coefficients. The most representative genera in each stream were identified by the Indicator Value Method. The spatial variations in the attributes of the assemblages were assessed using analysis of variance of null models. We collected 500 immature individuals of 23 genera and three families. Among the attributes analyzed only the composition and abundance showed significant spatial differences, with the highest mean abundance found in the Perobão Stream. Miathyria and Zenithoptera were the indicator genera of the Água Boa Stream and Erythrodiplax, Libellula, Macrothemis, Progomphus and Tramea were the indicator genera of the Perobão Stream.
\end{abstract}

KEYWORDS. Aquatic invertebrates, Iguatemi River basin, lotic environments, odonatofauna.

\begin{abstract}
RESUMO. Assembleia de imaturos de Odonata (Insecta, Anisoptera) em riachos sul-matogrossenses: implicações espaciais. Este trabalho investigou atributos de assembleias (composição, abundância, riqueza, diversidade e equitabilidade) e os gêneros mais representativos de Odonata, Anisoptera nos riachos Água Boa e Perobão, bacia do rio Iguatemi, MS, Brasil. Os riachos são de primeira ordem, apresentam extensão similar e são impactados pela remoção da mata ripária e assoreamento. As amostragens foram realizadas trimestralmente de março a dezembro/2008 nos trechos superior, intermediário e inferior de ambos os riachos. O teste de Mantel foi utilizado para verificar a influência da autocorrelação espacial sobre a composição de Odonata. Variações espaciais na composição foram sumarizadas através da Análise de Coordenadas Principais (PCoA) utilizando-se os resíduos do teste de Mantel. Os efeitos da correlação espacial na riqueza e abundância foram investigados através do correlograma espacial dos coeficientes do I de Moran. Para identificar os gêneros mais representativos em cada riacho foi utilizado o Método do Valor Indicador. As variações espaciais dos atributos das assembleias foram avaliadas por meio de análises de variância de modelos nulos. Foram coletados 500 indivíduos imaturos distribuídos em 23 gêneros e três famílias. Dentre os atributos analisados, apenas a composição e abundância apresentaram diferenças espaciais significativas, sendo o maior valor médio do último atributo registrado no riacho Perobão. Miathyria e Zenithoptera foram os gêneros indicadores do riacho Água Boa e Erythrodiplax, Libellula, Macrothemis, Progomphus e Tramea do Perobão.
\end{abstract}

PALAVRAS-CHAVE. Invertebrados aquáticos, bacia do rio Iguatemi, ambientes lóticos, odonatofauna.

Insects are widely found in freshwater environments (Souza \& COSTA, 2006) where they live associated with vegetation, water surface film, air-water interface and sediment, acting in the food chain as scavengers, herbivores or predators (MerRit \& Cummins, 1996). Among them, Odonata is usually recorded since this order encompasses approximately 5,860 species (popularly known as dragonflies), with high richness recorded for the Neotropics (KalKMAN et al., 2008) including 828 species identified in Brazil (Souza et al., 2007; Buzzi, 2013).

Odonata adults are terrestrial, mainly diurnal, active fliers and show complex territorial and sexual behaviors (Borror \& Delong, 1988; Souza et al., 2007). In turn, immature individuals are longitudinally distributed along water bodies according to their ecological requirements (Assis et al., 2004; REMSBURG \& TURNER, 2009) in search of food, oxygenated water and refuge (CORBET, 1980). These organisms are important functional components of aquatic ecosystems, with essential role in the food chain because they are predators at all life stages (CORBET, 1999; CARCHINI et al., 2007) and are preyed upon by fish, amphibians and reptiles (SOUZA \& COSTA, 2006). In addition to that, once immature individuals present long larval period, they are often used as environmental indicators (OsBorn, 2005; KalKMan et al., 2008; Simaika \& SamwaYs, 2011).

Several studies have shown the wide distribution of immature Odonata in streams where the composition and distribution of these insects are influenced by the interaction among physical, chemical, structural and hydrological variables (GIBBS et al., 2004; MALTCHIK et al., 2010; RAIO et al., 2011; Che Salmah et al., 2012; GómeZ-AnaYa et al., 2013). Thereby, changes in the water body characteristics can strongly influence the spatial and temporal distribution patterns of the odonatofauna (Buss et al., 2002, 2004; SilveIra et al., 2007).

Although freshwater ecosystems are subjected to 
unprecedented levels of human impacts (ABELL, 2002; SAUNDERS et al., 2002; ABELl et al., 2008), an anthropized landscape still supports a great diversity of Odonata $(\mathrm{KocH}$ et al., 2014). Specifically for the suborder Anisoptera, studies have shown that richness is higher in environments with lower vegetation cover (CARvalHo et al., 2013; JUEN et al., 2014) and their larvae exhibit considerable resistance to disturbed habitats (KALKMAN et al., 2008). Thus, environmental changes as removal of riparian forest can positively affect most species of Anisoptera since the majority is generalist and adapted to sites with higher solar incidence (Ferreira-Peruquetti \& De Marco, 2002; REMSBURG \& TURNER, 2009).

The Brazilian odonatofauna is still poorly known and most studies address the south and southeast regions (De Marco \& Vianna, 2005). For the Mato Grosso do Sul State (MS), information on this group is concentrated in the Pantanal region and mainly deal with taxonomic aspects (LoNGField, 1929; SANTos, 1944; SouZA et al., 1999, 2002; Heckman, 2006, 2008; Souza \& Costa, 2006; Pessace \& Costa, 2007; Dalzochio et al., 2011a,b). Specifically for the Iguatemi River basin, studies on odonatofauna are nonexistent, despite this river be one of the major tributaries of the Paraná River in the southern of Mato Grosso do Sul.

Considering the adaptability of Anisoptera in colonizing impacted aquatic environments, two first order streams of this basin showing similar length, geographic position and anthropogenic stressors (riparian forest removal and silting) where select to answer de following question: Are the streams also similar with respect to Anisoptera assemblages' attributes? To answer that, we investigated whether the composition, abundance, richness, diversity and evenness of Odonata Anisoptera assemblages are influenced by spatial variations, represented by the streams Água Boa e Perobão. Additionally, we evaluated which genera are more representative of the spatial (streams) components.

\section{MATERIAL AND METHODS}

Study area. The Água Boa and Perobão Streams are first order streams with 6.0 and $5.3 \mathrm{~km}$ long, respectively. They are located in the southern of Mato Grosso do Sul State and are part of the Iguatemi River basin, a right bank tributary of the Upper Paraná River. Fragments of the original vegetation remaining in the study area correspond to the Atlantic Forest biome (semideciduous forest). The region's climate is tropical of altitude with two distinct periods related to rainfall dynamics: a rainy period (October to March) and a dry period (April to September) with annual mean temperature between $21^{\circ} \mathrm{C}$ and $28^{\circ} \mathrm{C}$ and rainfall between 1,000 and 1,500 mm (Godoy, 1986; CAMpos, 2001).

The studied streams have their headwaters at the municipality of Japorã and flow through rural areas on the right bank of the Iguatemi River (Fig. 1). The Perobão Stream (located at $23^{\circ} 49^{\prime} 25.75^{\prime \prime} \mathrm{S} ; 5^{\circ} 26^{\prime} 43.54^{\prime \prime} \mathrm{W}$ and

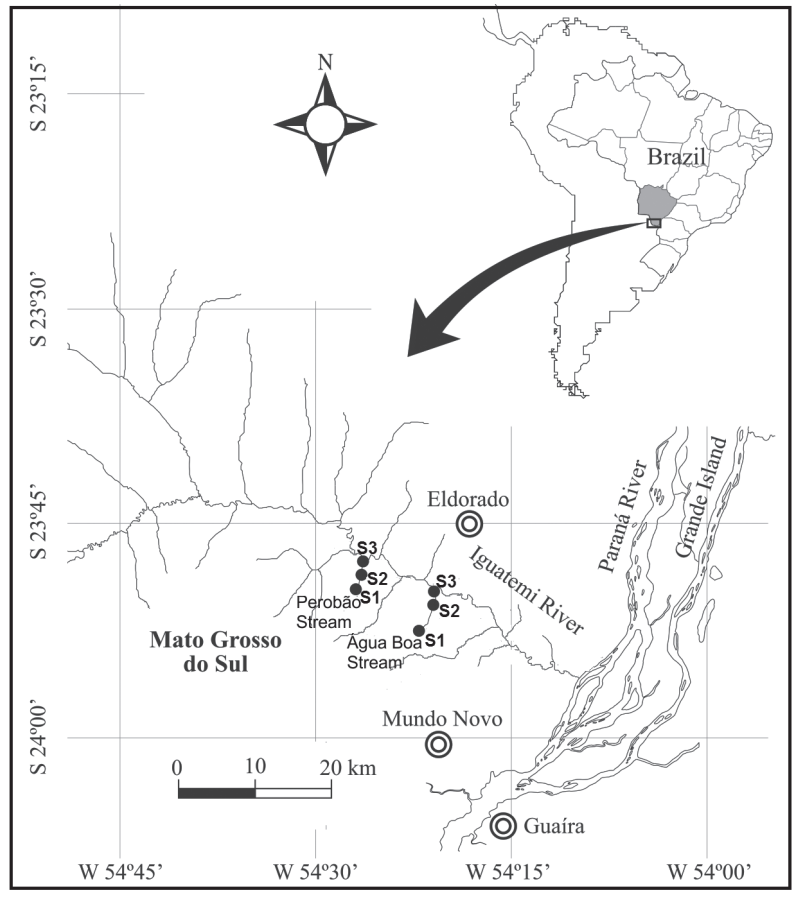

Fig. 1. Location of Perobão and Água Boa Streams, Iguatemi River basin, Brazil, and ampled sites at each stream (S1, upper stretch; S2, intermediate; S3, lower stretch).

$23^{\circ} 48^{\prime} 4.06^{\prime \prime}$; $54^{\circ} 26^{\prime} 25.36^{\prime \prime} \mathrm{W}$ ) has stretches with clay and sandy/rocky bottom, width ranging from 2.0 to 10.0 $\mathrm{m}$ and depth between 5.0 to $50.0 \mathrm{~cm}$. Slow water flow is observed only in the upper stretch while the other ones have riffles and pools.

The Água Boa Stream ( located at 2352'43.39'S; $54^{\circ} 21^{\prime} 55.59^{\prime \prime} \mathrm{W}$ and $23^{\circ} 50^{\prime} 9.33^{\prime \prime} \mathrm{S}$; $54^{\circ} 20^{\prime} 57.27^{\prime \prime} \mathrm{W}$ ) presents alternating stretches with clay, sandy and rocky bottom with width ranging from 2.0 to $6.0 \mathrm{~m}$ and depth between 12.0 to $90.0 \mathrm{~cm}$. The water flow is slow in the upper stretch and submerged aquatic vegetation is abundant. The intermediate stretch has riffles, backwaters and pools while the lower one is a straight channel with rapid water flow.

These habitats are subjected to intense human pressure. The replacement of native vegetation by agriculture and pasture is a remarkable characteristic of the regional occupation history (SÚAREZ \& Petrere JR., 2003). This process included the reduction of most of the original riparian vegetation. Currently, the vegetation is restricted to sparse trees and pasture grass is the predominant component. The soil is sandy and frequently impacted by gully erosion, intensifying the input of sediments to the streams; besides that, rural populations indiscriminately use the streams water for livestock, which aggravates the silting process due to animal trampling (personal observation).

Samplings. Samplings were conducted quarterly from March to November 2008 in three stretches (upper, intermediate and lower) of Água Boa and Perobão Streams.

For a better representativeness of odonatofauna at each stretch, we sampled the water surface, aquatic vegetation and sediment. Samples of the water surface 
were taken using a conical-cylindrical net $(0.5 \mathrm{~mm}$ mesh) submerged to $10 \mathrm{~cm}$ deep and hauled against the water flow for about two meters, performing five hauls in each stretch $\left(\right.$ area $\left.=2.6 \mathrm{~m}^{2}\right)$. To collect the individuals associated with the aquatic vegetation, we used a sieve $(3.0 \mathrm{~mm}$ mesh size), which was introduced into the vegetation, raised and agitated, totaling five consecutive repetitions (area $=0.98$ $\mathrm{m}^{2}$ ). For the capture of individuals in the sediment we used two gears: i) a D-net with $3.0 \mathrm{~mm}$ mesh size for the capture of the epifauna, which was dragged on the sediment in an approximate area of $1.0 \mathrm{~m}$ near marginal vegetation (area $=0.32 \mathrm{~m}^{2}$ ); ii) a Petersen type grab sampler for the capture of infauna, which was thrown on the sediment twice in a row, near the marginal region ( $\operatorname{area}=0.0415 \mathrm{~m}^{2}$ ). To optimize the sampling, we also included Odonata (from different substrates in the streams) caught along with fish samplings (not used in this study) through electrofishing (two dip nets and a portable generator - TOYAMA 1600, $220 \mathrm{~V}, \mathrm{DC})$. The length of each stretch sampled by this methodology was established according to FITZPATRICK et al. (1998). A single pass of dip nets was used to take immature Odonata in each stretch. At the end of each stretch it were installed blocking nets $(10.0 \times 2.0 \mathrm{~m} ; 5.0 \mathrm{~mm}$ mesh size) to capture the material carried by the flow. The use of these sampling methods is justified on the basis of differences in equipment efficiency on different substrates (Alves \& Strixino, 2003; Juen et al., 2007).

In the laboratory, samples were washed through a set of sieves with different mesh sizes (2.0, 1.0 and $0.5 \mathrm{~mm}$ ). Samples from the water surface, marginal vegetation, sediment and electrofishing were sorted using a transilluminated tray and placed in labeled vials and preserved in $70 \%$ alcohol. Immature individuals of Odonata were identified to the lowest possible taxonomic level, based on CarvalHo \& CALIL (2000), Costa et al. (2004), LeNCiONe (2005) and Souza et al. (2007).

Data analysis. The spatial distribution of immature Odonata was investigated for composition, abundance, richness, diversity and evenness, assessing whether such assemblage attributes vary between Água Boa and Perobão Streams. In order to standardize the numerical abundance, the results were expressed in individuals $/ 10 \mathrm{~m}^{2}$. Richness, diversity and evenness were obtained according to PIELOU (1969). Genera richness (S) was defined as the number of captured genera.

The influence of spatial correlation on the odonatofauna composition was analyzed by the Mantel Test using the PCord 5.0 software (MCCUNE \& MEFFORD, 1997). This method was used to test the hypothesis that the distances of the composition matrix are independent of the distance between the points of the geographic distance matrix. For the construction of similarity matrices, we used geographical coordinate data, converted into decimal degrees (Euclidean distance) and genera presence-absence data (Bray-Curtis distance). The Mantel test significance was evaluated based on Monte Carlo statistics after 9,999 permutations, with significance level of $p<0.05$. As the
Mantel test was significant, we use the residual of this test on a Principal Coordinate Analysis (PCoA - Bray-Curtis distance) which ordinated the streams based on composition similarity, controlling the effect of autocorrelation. The axes retained for interpretation were those showing the highest percentages of explanation. Patterns of odonatofauna composition were analyzed by trends in the ordination presented by the scores of the axes. We used the Past 2.17 software (HAMmER et al., 2001) to determine the attributes of Odonata assemblages and to run the PCoA.

Likely species composition, richness data are frequently spatially autocorrelated, typically leading to inflation of Type I error in statistical tests (LEGENDRE, 1993; Diniz-Filho et al., 2003; Dormann, 2007). Abundance data is also pointed out as a spatially structured variable (Fortin, 1999; Bourque \& Desrochers, 2006). Thus, we evaluated the effects of spatial correlation on richness and abundance using the spatial correlogram of Moran's I coefficients (DinIZ-FILHO et al., 2003) calculated for eight distance classes. The statement of positive and significant autocorrelation at short distances was the indicator of spatial structuration in the data. The effects of the spatial autocorrelation on diversity and evenness were inferred based on Moran's I results for species richness and abundance since such index are originated from simultaneous association of the richness and abundance. The Moran's I analysis was performed using the software SAM V.4.0 (RANGEL et al., 2010).

To check for significant spatial differences in the odonatofauna assemblage atributes we used the PCoA axes' scores and the values of abundance, richness, diversity and evenness to perform the ANOVA null models (GoTELLI \& Graves, 1996; Gotelli \& EnTSMinger, 2007). In this analysis, each attribute was the dependent variable and the streams (Água Boa and Perobão) were the independent variables. In the ANOVAs we used the EcoSim software (Gotelli \& ENTSMINGER, 2007) and entailed significant differences at $\mathrm{p}<0.05$ after 10,000 randomizations.

To identify the most representative genera (indicator) of each stream we used the Indicator Value Method - IndVal (DUfrêne \& LEGENDRE, 1997). This method combines information on the abundance and occurrence of a genus at one site generating an indicator value for each genus. The calculation of IndVal was conducted from data of relative abundance of each genus. When the randomization of the original matrix (Monte Carlo test; 10,000 permutations) indicated significant IndVal $(\mathrm{p}<0.05)$, the indicator genera were analyzed considering the variation patterns between streams. To calculate the IndVal we used the PCord 5.0 software (MCCUNE \& MEFFORD, 1997).

\section{RESULTS}

We collected 500 individuals of 23 genera and three families. Libellulidae was the most representative family, both in richness (12 genera) and number of individuals (290 individuals) followed by Gomphidae (eigth genera 
and 196 individuals) and Aeshnidae (three genera and 14 individuals). The Água Boa and Perobão Streams contained 20 and 16 genera, respectively. The taxa Cyanogomphus Selys, 1873, Gynacantha Rambur, 1842, Miathyria Kirby, 1889, Perythemis Hagen, 1861, Triacanthagyna Selys, 1883, Zenithoptera Selys, 1869 and Zonophora Selys, 1854 were exclusive to the Água Boa Stream and Gomphoides Selys, 1854, Libellula Linnaeus, 1758 and Micrathyria Kirby, 1889 were exclusive to the Perobão Stream (Tab. I).

The similarity matrix of Odonata assemblages was significantly correlated with the matrix of geographical distances of the streams (Mantel test: $\mathrm{R}=0.32459 ; \mathrm{p}<0.05$ ), indicating that the odonatofauna of each stream is spatially dependent. In this way, the composition was evaluated by the PCoA based on the Mantel Residual Test. The first axis of the PCoA explained $89.9 \%$ of data variability and so it was the only one analyzed. The ordination showed a clear spatial segregation (Fig. 2). This result was confirmed by ANOVA that evidenced significant differences in Odonata composition between the streams for the axis $1(\mathrm{OI}=1894.3$; $\left.\mathrm{p}_{\mathrm{obs}} \geq \mathrm{p}_{\mathrm{esp}}=0.0001\right)$.

Regarding autocorrelation on assemblage attributes, we did not observe positive autocorrelation at short distance classes $(914 \mathrm{~m}$ ) for richness (Moran's $\mathrm{I}=0.01 ; \mathrm{p}=0.626$ ) and abundance (Moran's $I=0.067 ; p=0.313$ ). Considering the spatial variation, the ANOVA revealed that only the mean values of abundance showed significant differences between the streams (Fig. 3).

The IndVal revealed that Miathyria and Zenithoptera were the indicator genera of the Água Boa Stream, while

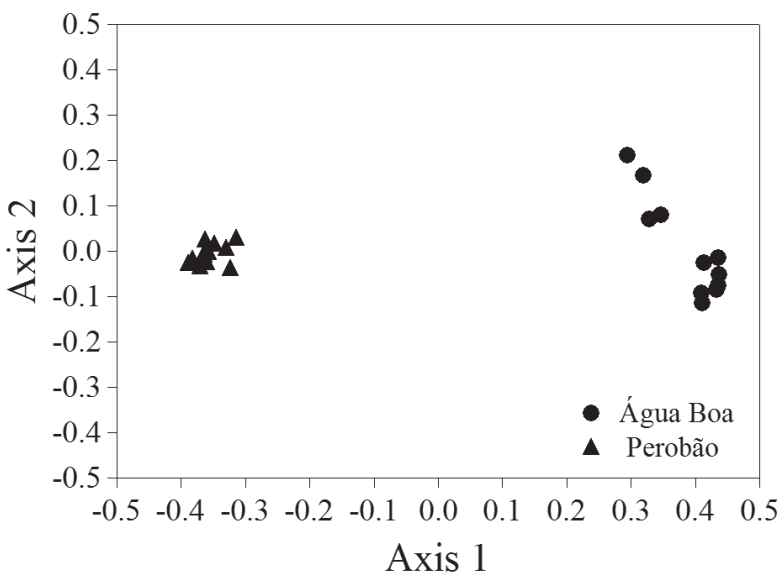

Fig. 2. Scatter plot of the scores of the first two PCoA axes.

Erythrodiplax Brauer, 1868, Libellula, Macrothemis Hagen, 1868, Progomphus Selys, 1854 and Tramea Hagen, 1861 were the indicator genera of the Perobão Stream (Tab. II).

\section{DISCUSSION}

The suborder Anisoptera presents a wide geographical distribution and makes up most of the Odonata genera occurring in Brazil (BuzzI, 2013). Libellulidae has been identified as the most diverse and numerically expressive family of this suborder (COSTA \& OLDRINI, 2005; De Marco \& Vianna, 2005; Ramírez, 2010) which is consistent with our results. The diversity and abundance of

Tab. I. Composition, number of individuals (N) and relative abundance (\%) of the imature Odonata sampled at Água Boa and Perobão Streams, Iguatemi River basin, Brazil.

\begin{tabular}{|c|c|c|c|c|}
\hline \multirow{2}{*}{ TAXA } & \multicolumn{2}{|c|}{ Água Boa } & \multicolumn{2}{|c|}{ Perobão } \\
\hline & $\mathrm{N}$ & $\%$ & $\mathrm{~N}$ & $\%$ \\
\hline \multicolumn{5}{|l|}{ Aeshnidae } \\
\hline Coryphaeschna Williamson, 1903 & 02 & 1.4 & 05 & 1.4 \\
\hline Gynacantha Rambur, 1842 & 06 & 4.3 & 0 & 0.0 \\
\hline Triacanthagyna Selys, 1883 & 01 & 0.7 & 0 & 0.0 \\
\hline \multicolumn{5}{|l|}{ Gomphidae } \\
\hline Aphylla Selys, 1854 & 02 & 1.4 & 08 & 2.2 \\
\hline Cyanogomphus Selys, 1873 & 02 & 1.4 & 0 & 0.0 \\
\hline Erpetogomphus Selys, 1858 & 05 & 3.6 & 02 & 0.6 \\
\hline Gomphoides Selys, 1854 & 0 & 0.0 & 01 & 0.3 \\
\hline Phyllocycla Calvert, 1948 & 06 & 4.3 & 38 & 10.5 \\
\hline Phyllogomphoides Belle, 1970 & 03 & 2.2 & 01 & 0.3 \\
\hline Progomphus Selys, 1854 & 06 & 4.3 & 111 & 30.7 \\
\hline Zonophora Selys, 1854 & 11 & 7.9 & 0 & 0.0 \\
\hline \multicolumn{5}{|l|}{ Libellulidae } \\
\hline Brechmorhoga Kirby, 1894 & 09 & 6.5 & 12 & 3.3 \\
\hline Elasmothemis Westfall, 1988 & 25 & 18.0 & 06 & 1.7 \\
\hline Erythrodiplax Brauer, 1868 & 02 & 1.4 & 23 & 6.4 \\
\hline Gynothemis Calvert in Ris, 1909 & 05 & 3.6 & 03 & 0.8 \\
\hline Libellula Linnaeus, 1758 & 0 & 0.0 & 24 & 6.6 \\
\hline Macrothemis Hagen, 1868 & 01 & 0.7 & 38 & 10.5 \\
\hline Miathyria Kirby, 1889 & 12 & 8.6 & 0 & 0.0 \\
\hline Micrathyria Kirby, 1889 & 0 & 0.0 & 02 & 0.6 \\
\hline Orthemis Hagen, 1861 & 02 & 1.4 & 17 & 4.7 \\
\hline Perythemis Hagen, 1861 & 01 & 0.7 & 0 & 0.0 \\
\hline Tramea Hagen, 1861 & 05 & 3.6 & 70 & 19.4 \\
\hline Zenithoptera Selys, 1869 & 33 & 23.7 & 0 & 0.0 \\
\hline TOTAL & 139 & 100 & 361 & 100 \\
\hline
\end{tabular}



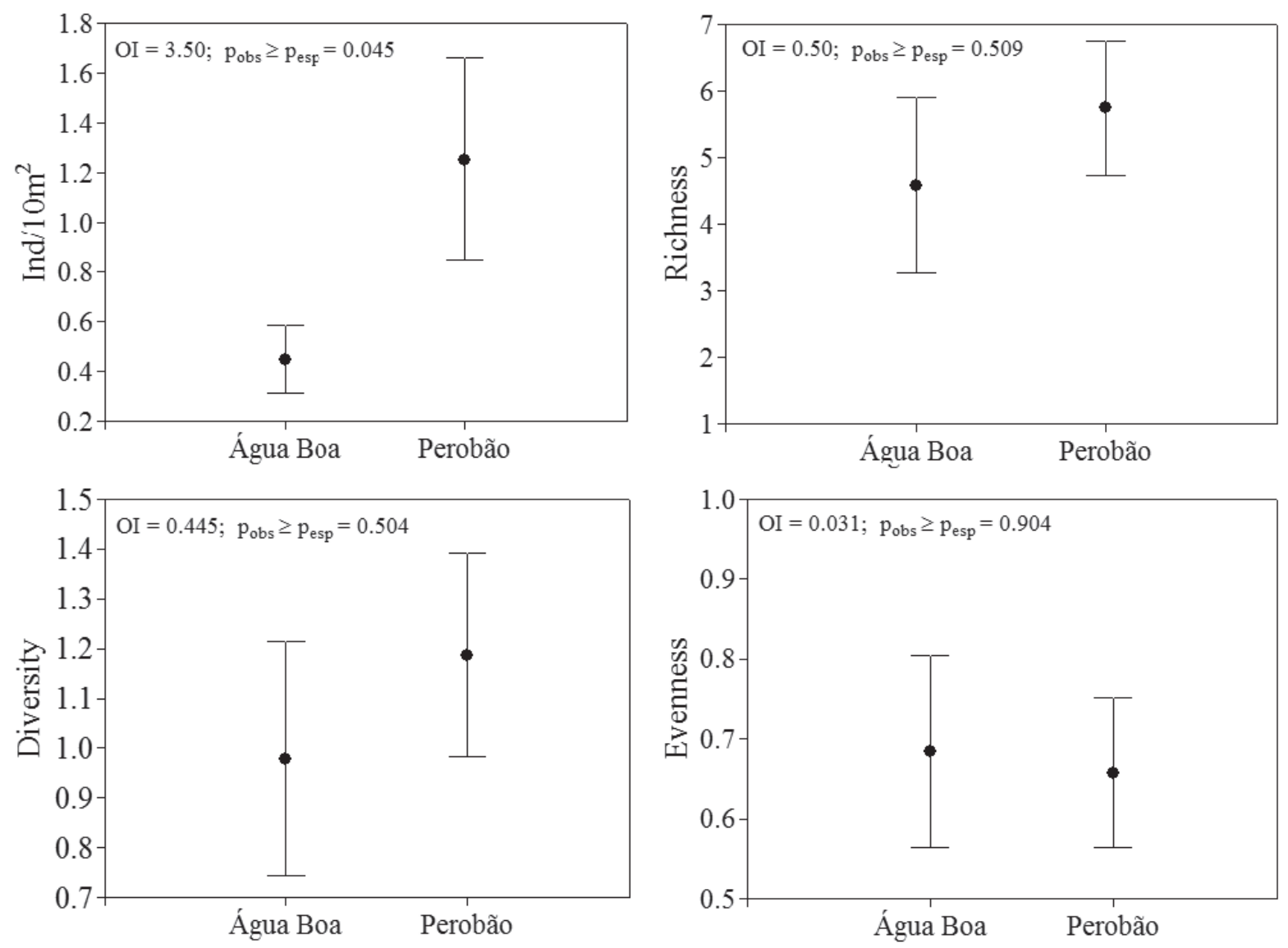

Fig. 3. Mean values of abundance, richness, diversity and evenness of the immature Odonata sampled at Água Boa and Perobão Streams, Iguatemi River basin, Brazil. Means are represented by circles and standard error by vertical bars.

Tab. II. Summary of the Indicator Value Method: relative abundance, relative frequency and indicator value for each stream. Only the species with significant values are shown. Bold values indicate significant indicator values $(\mathrm{p}<0.05$, Monte Carlo test).

\begin{tabular}{|c|c|c|c|c|c|c|}
\hline \multirow{2}{*}{ Taxa } & \multicolumn{2}{|c|}{ Relative abundance } & \multicolumn{2}{|c|}{ Relative frequency } & \multicolumn{2}{|c|}{ Indicator value } \\
\hline & Água Boa & Perobão & Água Boa & Perobão & Água Boa & Perobão \\
\hline Miathyria & 100 & 0 & 36 & 0 & 36 & 0 \\
\hline Zenithoptera & 100 & 0 & 36 & 0 & 36 & 0 \\
\hline Erythrodiplax & 6 & 94 & 18 & 50 & 1 & 47 \\
\hline Libellula & 0 & 100 & 0 & 58 & 0 & 58 \\
\hline Macrothemis & 3 & 97 & 9 & 58 & 0 & 57 \\
\hline Progomphus & 4 & 96 & 27 & 83 & 1 & 80 \\
\hline Tramea & 6 & 94 & 27 & 58 & 2 & 55 \\
\hline
\end{tabular}

this family have been commonly associated with structural characteristics and conservation of the habitats where they occur. Immature individuals of this group preferably inhabit aquatic environments with reduced or absent riparian vegetation, being often found in open areas (KALKMAN et al., 2008; JuEN et al., 2014).

Moreover, studies have reported the dominance of Libellulidae immature in streams near pastures, with degraded riparian forests or in silted streams (CORTEZZI et al., 2009; DALzochio et al., 2011a). Our results confirm this pattern since most of the stretches sampled in both streams are shallow and the surroundings consist mainly of grass pastures and sparse fragments of riparian vegetation. Combined with the adaptability to human environments, another factor associated with the representativeness of this family is the large body size of adults compared to other families of this suborder, which therefore increases the dispersal ability (KALKMAN et al., 2008; DALzOCHIO et al., 2011a).

Among the 23 genera identified only 12 were common to both streams, which reflect a spatially distinct composition pattern. This variation in the composition between the streams can be attributed to different factors. Firstly, to local and regional historical colonization events, which according to OLIVEIRA et al. (1997), are the main responsible for the community characteristics, particularly its composition. Secondly, to physical and structural characteristics of the streams, particularly the nature of the substrate, which can control the distribution of immature Odonata (JUEN et al., 2007). 
Spatial and/or temporal changes in the substrate are often observed in streams, particularly considering the physical structure, organic composition, stability and heterogeneity (RibeIRo \& UiedA, 2005). As a result, we can observe a mosaic of microhabitats (KIKUCHI \& UIEDA, 1998), which allow the establishment of Odonata species with different modes of life, such as swimmers, clingers, climbers, sprawlers, burrowers and sprawler-burrowers (Carvalho \& Nessimian, 1998). The heterogeneous environmental structure of the Perobão Stream, with lentic stretches (upper reaches), backwater, rapids and pools (intermediate and lower stretches) and varied substrate (clay and sand/pebbles) should provide greater number of micro-habitats for colonization by Odonata, justifying their higher abundance at this stream. Probably, these structural features particularly favored the populations of Progomphus and Tramea, which together accounted for more than $50.0 \%$ of catches in Perobão. The predominance of these genera among Odonata was also found in other Brazilian regions (KIKUCHI \& UIEDA, 2005; FigUEIREDO et al., 2013; PIRES et al., 2013).

Although having different ecological requirements and habits, Progomphus and Tramea along with Erythrodiplax, Macrothemis and Libellula were the indicator genera of the Perobão Stream. Progomphus is mainly found in lotic environments, presents burrowing habit adapted to dig and burrow in streams' sandy beds (Assis et al., 2004; Costa et al., 2004; RAmírez, 2010). On the other hand, Tramea and Erythrodiplax occur in lentic habitats and have sprawling habit, wherein the first colonizes sediments mainly composed of clay, sand and stones, whereas the second preferably dwells densely vegetated sites (CARVALHO \& NeSSIMIAN, 1998; Costa et al., 2004; FigueIREDO et al., 2013). Libellula occurs in lotic environments, colonizing debris and presents sprawlingburrowing habit, while Macrothemis, also with sprawlingburrowing habit, occurs both, in streams with rapid waters and streams with low current flow dwelling sandy and clay substrates (CARvalho \& Nessimian, 1998). Therefore, the successful establishment of these genera should be related mainly to the mosaic of microhabitats found at the Perobão Stream, as described above.

Beyond that, Zenithoptera and Miathyria were the indicator taxa of the Água Boa Stream. It differs from the Perobão Stream by presenting a high amount of submerged vegetation in lentic reaches, which must determine the colonization of Zenithoptera, Elasmothemis Westfall, 1988 and Miathyria, as these genera are known to occupy mainly lentic sites with sandy substrate and abundant submerged vegetation (Franco \& TAKEDA, 2002; Costa et al., 2004). Although Elasmothermis was not classified as an indicator of the Água Boa Stream, it was among the most abundant taxa in this stream.

Finally, the results pointed out that among the assemblages attributes investigated, only the composition and abundance of Anisoptera were different among the studied streams. Once structural variables of habitats are characterized as an important tool to explain the distribution of immature Odonata, future work addressing the association of the odonatofauna with such variables may contribute to achieve more accurate answers about the patterns found herein.

Acknowledgements. The authors would like to thank the Fundação de Apoio ao Desenvolvimento do Ensino, Ciência e Tecnologia do Estado de Mato Grosso do Sul (FUNDECT) for financial support. The authors also thank C. A. Fernandes for drawning the Figure 1. Work by D. Bailly is supported by CAPES/PNPD post-doctoral fellowship.

\section{REFERENCES}

Abell, R. 2002. Conservation biology for the biodiversity crisis : a freshwater follow-up. Conservation Biology 16(5):1435-1437.

Abell, R.; Thieme, M. L.; Revenga, C.; Bryer, M.; Kottelat, M.; Bogutskaya, N.; CoAd, B.; MandraK, N.; Balderas, S. C.; Bussing, W.; Stiassny, M. L. J.; Skelton, P.; Allen, G. R.; Unmack, P.; Naseka, A.; NG, R.; Sindorf, N.; Robertson, J.; Armijo, E.; Higgins, J. V.; Heibel, T. J.; Wikramanayake, E.; LóPez, H. L.; Reis, R. E.; LundberG, J. G.; Pérez, M. H. S. \& Petry, P. 2008. Freshwater ecoregions of the world : a new map of biogeographic units for freshwater biodiversity conservation. BioScience 58(5):403-414.

Alves, R. G. \& Strixino, G. 2003. The sampling of benthic macroinvertebrates using two different methods: waiting trays and Ekman collector. Acta Limnologica Brasiliensia 15(3):1-6.

Assis, J. C. F.; Carvalho, A. L. \& Nessimian, J. L. 2004. Composição e preferência por micro-habitat de imaturos de Odonata (Insecta) em um trecho de baixada do Rio Ubatiba, Maricá-RJ, Brasil. Revista Brasileira de Entomologia 48(2):273-282.

Borror, D. J. \& Delong, D. M. 1988. Introdução ao estudo dos insetos. São Paulo, Edgard Blücher. 653p.

Bourque, J. \& Desrochers, A. 2006. Spatial aggregation of forest songbird territories and possible implications for area sensitivity. Available at $<$ http://www.ace-eco.org/voll/iss $2 /$ art3/>. Accessed on August 28, 2014.

Buss, D. F.; Baptista, D. F.; Nessimian, J. L. \& EgLer, M. 2004. Substrate specificity, environmental degradation and disturbance structuring macroinvertebrate assemblages in neotropical streams. Hydrobiology 518(1):179-188.

Buss, D. F.; Baptista, D. F.; Silveira, M. P.; Nessimian, J. L. \& Dorvillé, L. F. M. 2002. Influence of water chemistry and environmental degradation on macroinvertebrates assemblages in a river basin in south-east Brazil. Hydrobiology 481(1):125-136.

Buzzi, Z. J. 2013. Entomologia didática. Rio de Janeiro, Technical Books. 579p.

CAmpos, J. B. 2001. Parque Nacional de Ilha Grande: re-conquista e desafios. Maringá, Instituto Ambiental do Paraná. 118p.

Carchini, G.; Della-Bella, V.; Solimini, A. G. \& Bazzanti, M. 2007. Relationships between the presence of odonate species and environmental characteristics in lowland ponds of central Italy. Journal of Limnology 43(2):81-87.

Carvalho, A. L. \& Calil, E. R. 2000. Chaves de identificação para as famílias de Odonata (Insecta) ocorrentes no Brasil - adultos e larvas. Papéis Avulsos de Zoologia 41(15):423-441.

Carvalho, A. L. \& Nessimian, J. L. 1998. Odonata do estado do Rio de Janeiro, Brasil: hábitats e hábitos das larvas. Oecologia Brasiliensis 5:3-28.

Carvalho, F. G.; Pinto, N. S.; Oliveira-Júnior, J. M. B. \& Juen, L. 2013. Effects of marginal vegetation removal on Odonata communities. Acta Limnologica Brasiliensia 25(1):10-18.

Che Salmah, M. R.; Al-Shami, S. A.; Md Shah, A. S. R.; Ahmad, A. H. \& MAN, A. 2012. Effects of herbicides on Odonata communities in a rice agroecosystem. Environmental Toxicology and Chemistry 94:1188-1198.

Corbet, P. S. 1980. Biology of Odonata. Annual Review of Entomology 25:189-217.

1999. Dragonflies: behavior and ecology of Odonata. London, Comstock Pub Association. 829p. 
Cortezzi, S. S.; Bispo, P. C.; Paciencia, G. P. \& Leite, R. C. 2009. Influência da ação antrópica sobre a fauna de macroinvertebrados aquáticos em riachos de uma região de Cerrado do sudoeste do Estado de São Paulo. Iheringia, Série Zoologia 99(1):36-43.

Costa, J. M. \& Oldrini, B. B. 2005. Diversidade e distribuição dos Odonata (Insecta) no estado do Espírito Santo, Brasil. Publicações Avulsas do Museu Nacional 107:1-15.

Costa, J. M.; Souza, L. O. I. \& Oldrini, B. B. 2004. Chave para identificação das famílias e gêneros das larvas conhecidas de Odonata do Brasil: comentários e registros bibliográficos. Publicações Avulsas do Museu Nacional 99:1-44.

Dalzochio, M. S.; Costa, J. M. \& Manoel, A. 2011a. Diversity of Odonata (Insecta) in lotic systems from Serra da Bodoquena, Mato Grosso do Sul State, Brazil. Revista Brasileira de Entomologia 55(1):88-94.

Dalzochio, M. S.; Souza, L. O. I.; UchoA, M. A. \& Costa, J. M. 2011 b. First records of Odonata (insecta) from the Bodoquena Mountains, Mato Grosso do Sul, Brazil. Entomo Brasilis 4(3):135-138.

De Marco, P. JR. \& ViannA, D. M. 2005. Distribuição de esforço de coleta de Odonata no Brasil: subsídios para escolha de áreas prioritárias para levantamentos faunísticos. Lundiana 6:13-26.

Diniz-Filho, J. A. F.; Bini, L. M. \& Hawkins, B. A. 2003. Spatial autocorrelation and red herrings in geographical ecology. Global Ecology Biogeography 12(1):53-64.

Dormann, C. F. 2007. Effects of incorporating spatial autocorrelation into the analysis of species distribution data. Global Ecology Biogeography 16(2):129-138.

Dufrêne, M. \& LEGENDRE, P. 1997. Species assemblages and indicator species: The need for a flexible asymmetrical approach. Ecological Monographs 67(3):345-366.

Ferreira-Peruquetti, P. S. \& De Marco, P. JR. 2002. Efeito da alteração ambiental sobre comunidades de Odonata em riachos de Mata Atlântica de Minas Gerais, Brasil. Revista Brasileira de Zoologia 19(2):317-327.

Figueiredo, N. S. B.; Pires, M. M.; Davanso, R. C. S. \& Kotzian, A. B. 2013. Diversity of larvae Odonata (Insecta) River Ibicuí basin, Rio Grande do Sul, Brazil. Ciência e Natura 35(2):84-94.

FitzPatrick, F. A.; Waite, I. R.; D'Arconte, P. J.; Meador, M. R.; Maupin, M. A. \& Gurtz, M. E. 1998. Revised methods for characterizing stream habitat in the national water-quality assessment program. U.S. Geological Survey Water-Resources Investigations Report 98-4052. Available at $<$ http://pubs.usgs.gov/wri/wri984052/>. Accessed on August 28, 2014.

ForTIN, M. J. 1999. Effects of sampling unit resolution on the estimation of sapatial autocorrelation. Ecoscience 6(4):636-641.

Franco, G. M. S. \& TAKEDA, A. M. 2002. Spatial and temporal variation of Odonata larvae associated with macrophytes in two floodplain lakes from the upper Paraná River, Brazil. Acta Scientiarum 24(2):345-351

Gibbs, E.; Bradeen, B. \& Boland, D. 2004. Spatial and temporal segregation among six species of coexisting Ophiogomphus (Odonata: Gomphidae) in the Aroostook River, Maine. Northeastern Naturalist 11:295-312.

Godoy, M. P. 1986. Peixes e pesca do rio Paraná: área do future reservatório da Usina Hidrelétrica de Ilha Grande. Florianópolis, Eletrosul. 148p.

Gómez-Anaya, J. A.; Novelo-Gutiérrez, R. \& Ramírez, A. 2013. Temporal variation in Odonata larval assemblage diversity in a lowland stream in western Mexico. Odonatologica 42(4):309-323.

Gotelli, N. J. \& ENTSMinger, G. L. 2007. EcoSim: null models software for ecology. Version 7.0. Jericho, Vermont, Acquired Intelligence Inc. \& Kesey-Bear. Available at $<\mathrm{http}$ ://garyentsminger.com/ecosim.htm>.

Gotelli, N. J. \& Graves, G. R. 1996. Null models in ecology. Washington, Smithsonian Institution Press. 368p.

Hammer, Ø.; Harper, D. A. T. \& Ryan, P. D. 2001. PAST: Paleontological statistics software package for education and data analysis. Available at $<$ http://palaeo-electronica.org/2001_1/past/issue1_01. htm, 2001 $\geq$. Accessed on September, 12, 2014.

Heckman, C. W. 2006. Encyclopedia of South American aquatic insects: Odonata - Anisoptera. Illustrated keys to known families, genera, and species in South America. Olympia, Springer Science. $725 \mathrm{p}$.
2008. Encyclopedia of South American aquatic insects: Odonata - Zygoptera. Illustrated keys to known families, genera, and species in South America. Dordrech, Springer. 694p.

Juen, L.; CABette, H. S. R. \& De MarCo, P. JR. 2007. Odonate assembrage structure in relation to basin and aquatic habitat structure in Pantanal wetlands. Hydrobiologia 579:125-134.

Juen, L.; Oliveira-Júnior, J. M. B.; Shimano, Y.; Mendes, T. P. \& CABette, H. S. R. 2014. Composição e riqueza de Odonata (Insecta) em riachos com diferentes níveis de conservação em um ecótono Cerrado-Floresta Amazônica. Acta Amazonica 44(2):175-184.

Kalkman, V. J.; Clausnitzer, V.; Dijkstra, K. D. B.; OrR, A. G.; Paulson, D. R. \& Tol, J. V. 2008. Global diversity of dragonflies (Odonata) in freshwater. Hydrobiologia 595:351-363.

KIKUCHI, R. M. \& UiedA, V. S. 1998. Composição da comunidade de invertebrados de um ambiente lótico tropical; e variação espacial e temporal. Oecologia Brasiliensis 5(1):157-173.

2005. Composição e distribuição dos macroinvertebrados em diferentes substratos de fundo de um riacho no município de Itatinga, São Paulo, Brasil. Entomología y Vectores 12(2):193-231.

Koch, K.; Wagner, C. \& SAHLÉN, G. 2014. Farmland versus forest: comparing changes in Odonata species composition in western and eastern Sweden Insect. Conservation and Diversity 7:22-31.

LEGENDRE, P. 1993. Spatial autocorrelation: trouble or new paradigm? Ecology 74(6):1659-1673.

LENCIONE, F. A. A. 2005. The damselflies of Brazil: an illustrated guide 1- non -Coenagrionidae families. São Paulo, All Print Editora. 324p.

LONGFIELD, C. 1929. A list of Odonata of the state of Mato Grosso, Brazil. Transactions of the Entomological Society of London 77:125-139.

Maltchik, L.; Steinert, C.; Kotzlan, A. B. \& Pires, M. M. 2010. Responses of Odonate communities to environmental factors in Southern Brazil wetlands. Journal of the Kansas Entomological Society 83(3):208-220.

Mccune, B. \& MefFord, M. J. 1997. PC-ORD: multivariate analysis of ecological data. Version 3.0. Oregon, MjM Software Design.

Merritt, R. W. \& Cummins, K. W. 1996. An introduction to the aquatic insects of North America. Dubuque, Kendall/Hunt Publishing. 861p.

Oliveira, L. G.; BisPo, P. C. \& SÁ, N. C. 1997. Ecologia de comunidades de insetos bentônicos (Ephemeroptera, Plecoptera e Trichoptera), em córregos do Parque Ecológico de Goiânia, Goiás, Brasil. Revista Brasileira de Zoologia 14(2):867-876.

OsBorn, R. 2005. Odonata as indicators of habitat quality at lakes in Louisiana, United States. Odonatologica 34:259-270.

Pessacq, P. \& Costa, J. M. 2007. Three new species of Peristicta Hagen in Selys (Odonata: Zygoptera: Protoneuridae). Neotropical Entomology 36(1):46-52.

Pielou, E. C. 1969. Association test versus homogeneity tests: their use in subdividing quadrats into groups. Vegetatio 19:4-18.

Pires, M. M.; Kotzian, C. B.; Spies, M. R. \& Neri, D. B. 2013. Diversity of Odonata (Insecta) larvae in streams and farm ponds of a montane region in southern Brazil. Biota Neotropica 13(3):259-267.

Raio, C. B.; Espinoza, A. A. \& Bennemann, S. T. 2011. Diversidade e similaridade entre populações de insetos aquáticos em riachos de primeira e segunda ordem, sul do Brasil. Semina: Ciências Biológicas e da Saúde 32(1):69-76.

Ramírez, A. 2010. Odonata. Revista de Biologia Tropical 58(Suppl. 4): 97-136.

Rangel, T. F.; Diniz-Filho, J. A. F. \& Bini, L. M. 2010. SAM: a comprehensive application for Spatial Analysis in Macroecology. Ecography 33(1):46-50.

Remsburg, A. J. \& Turner, M. G. 2009. Aquatic and terrestrial drivers of dragonfly (Odonata) assemblages within and among north-temperate lakes. Journal of the North American Benthological Society 28(1):44-56.

Ribeiro, L. O. \& UiedA, V. S. 2005. Estrutura da comunidade de macroinvertebrados bentônicos de um riacho de serra em Itatinga, São Paulo, Brasil. Revista Brasileira de Zoologia 22(3):613- 618.

Santos, N. D. 1944. Libellulidae coligidos em Ilha Seca (Estado de São Paulo), Salobra e Bodoquena (Estado de Mato Grosso) pela Comissão Científica do Instituto Oswaldo Cruz (Insecta: Odonata). Boletim do Museu Nacional de Zoologia 16:1-10. 
Saunders, D. L.; Meeuwig, J. J. \& Vincent, A. C. J. 2002. Freshwater protected areas: strategies for conservation. Conservation Biology 16(1): 30-41.

Silveira, M. P.; Buss, D. F.; Nessimian, J. L. \& Baptista, D. F. 2007. Spatial and temporal distribution of benthic macroinvertebrates in southeastern Brazilian river. Brazilian Journal Biology 66(2):623632.

Simaika, J. P. \& Samways, M. J. 2011. Comparative assessment of indices of freshwater habitat conditions using different invertebrate taxon sets. Ecological Indicators 11:370-378.

SouzA, L. O. I. \& CosTA, J. M. 2006. Inventário da odonatofauna no Complexo Aporé-Sucuriú. In: Pagotto, T. C. S. \& Souza, P. R. eds. Biodiversidade do Complexo Aporé-Sucuriú. Subsídios à conservação e manejo do bioma Cerrado. Campo Grande, Editora UFMS, p. 81-88.
Souza, L. O. I.; Costa, J. M. \& SAntos, T. C. 1999. Description of larva of Planiplax phoenicura from Pantanal Sul-matogrossense, Brazil (Anisoptera: Libellulidae). Odonatologica 28(2):159-163.

Souza, L. O. I.; Costa, J. M. \& Espindola, L. A. 2002. Description of the last instar larva of Oligoclada laetitia Ris, 1911 and comparison with other Libellulidae (Anisoptera). Odonatologica 31(4):403-407.

Souza, L. O. I.; Costa, J. M. \& Oldrini, B. B. 2007. Odonata. In: Froehlich, C. G. eds. Guia on-line: Identificação de larvas de insetos aquáticos do estado de São Paulo. Available at $<$ http://sites.ffclrp.usp. br/aguadoce/Guia_online/index.htm>. Accessed on May 18, 2014.

Súarez, Y. R. \& Petrerere JR., M. 2003. Associações de espécies de peixes em ambientes lóticos da bacia do rio Iguatemi, Estado do Mato Grosso do Sul. Acta Scientiarum 25(2):361-367. 